Article

\title{
Effect of Ozone Treatment on Flavonoid Accumulation of Satsuma Mandarin (Citrus unshiu Marc.) during Ambient Storage
}

\author{
Xiangrong Zhu ${ }^{1,2,3}$, Jing Jiang ${ }^{3}$, Chunxiao Yin ${ }^{3}$, Gaoyang $\mathrm{Li}^{1,3}$, Yueming Jiang ${ }^{2, *}$ and \\ Yang Shan 1,3,* \\ 1 Hunan Key Lab of Fruits \&Vegetables Storage, Processing, Quality and Safety, Hunan Agricultural Product \\ Processing Institute, Hunan Academy of Agricultural Sciences, Changsha 410125, China; \\ xiangrongchu@163.com (X.Z.); lgy7102@yahoo.com.cn (G.L.) \\ 2 South China Botanical Garden, Chinese Academy of Sciences, Guangzhou 510650, China \\ 3 Longping branch, Graduate School of Hunan University, Changsha 410125, China; \\ Jingjiang1995@163.com (J.J.); chunxiaoyin@scbg.ac.cn (C.Y.) \\ * Correspondence: ymjiang@scbg.ac.cn (Y.J.); shanyang_jgs@163.com (Y.S.)
}

Received: 11 November 2019; Accepted: 1 December 2019; Published: 3 December 2019

\begin{abstract}
This study aimed to compare the flavonoid accumulation between ozone-treated and untreated Satsuma mandarin (Citrus unshiu Marc.) fruits. The fruits exposed to gaseous ozone were found to have higher antioxidant activities and content of flavonoid during the storage period by ultra-high performance liquid chromatography (UPLC). To reveal the molecular regulation of flavonoid accumulation by ozone, chalcone synthase ( $\mathrm{CHS})$, chalcone isomerase $(\mathrm{CHI}), \beta-1,3$-glucanase $(G L U)$, chitinase $(C H T)$, phenylalanine ammonia-lyase $(P A L)$, and peroxidase $(P O D)$ were identified and their expression was examined by quantitative real-time polymerase chain reaction (q-PCR). These results support the promising application of ozone treatment as a safe food preservation technique for controlling postharvest disease and extending shelf-life of harvested Satsuma mandarin.
\end{abstract}

Keywords: satsuma mandarin; ozonation; flavonoids accumulation; antioxidant capacity; gene expression

\section{Introduction}

Citrus fruit, the most important fruits produced in commercial scale in the world and China, are susceptible to postharvest fungal decay by Penicillium italicum and Penicillium digitatum, resulting in important economic losses [1]. The use of chemical fungicides to control fungal diseases during the postharvest storage of citrus fruits may bring potential risks to human health and the environment [2]. Therefore, there is an obvious demand for other approaches to reduce decay and to prolong postharvest life of citrus fruits [3].

Ozone $\left(\mathrm{O}_{3}\right)$ was approved by the U.S. Food and Drug Administration (FDA) as an anti-microbial agent for food storage in 2001 [4]. Ozone readily decomposes into $\mathrm{O}_{2}$ without leaving any residue and accumulation of toxic secondary metabolites [5]. Ozone treatment has been effective in prolonging the shelf-life of papaya [6], wine grapes [7], black mulberries [8], peppers [9], strawberry [10], cucumbers and zucchini [11]. Previous research showed that $\mathrm{O}_{3}$ treatment increases antioxidant capacity, total phenol, and flavonoid content in table grapes [12] and pears [13]. Furthermore, it was noted that the strong oxidative properties of $\mathrm{O}_{3}$ could influence antioxidant and defense-related enzyme activities [14-16]. Total phenolics content has previously been found to be increased in ozone-treated banana [17], papaya [18], kiwi [19], green asparagus [20], and globe artichoke [21] when compared with control fruits and vegetables. The possible mechanism may be related to increased activity of 
phenylalanine ammonia-lyase (PAL) [22,23], SOD [16,24] and peroxidase (POD) [25] or decreased activity of polyphenol oxidase (PPO) [20,26]. These enzymes are capable of degrading polymers of fungal cell walls and are therefore thought to be involved in plant defence mechanisms by reducing fungal growth, and thus, lowering the rate of decay [16,23].

However, information available on changes of flavonoid content, antioxidant capacities as well as related-gene expression in Satsuma mandarin during ozone treatment is limited. Therefore, the objective of this study was to investigate the effects of ozone treatment on content of flavonoid, the antioxidant capacity, key genes expression, and some important characteristics, such as respiratory rate, decay rate, and colour change of Satsuma mandarin and to fully understand the inter-relationship among flavonoid compounds, the antioxidant capacity, key genes, as well as the association with postharvest quality.

\section{Materials and Methods}

\subsection{Fruit Material}

Satsuma mandarin (Citrus unshiu Marc.) fruit was harvested from a large-scale commercial orchard in Shaoguan city, Guangdong Province, China. They were transported to the laboratory, selected for uniformity of shape, size, color, appearance, and then randomly divided into six groups stored at ambient temperature $\left(25 \pm 1{ }^{\circ} \mathrm{C}\right)$. The citrus peels were manually separated and frozen in liquid nitrogen immediately and kept at $-80^{\circ} \mathrm{C}$ until needed for flavonoid and q-PCR analysis.

\subsection{Ozone Treatments}

Ozone was pumped into the container from ozone generator (Tianjin, China), and the concentration was kept at $2.5 \mu \mathrm{g} \mathrm{L}-1$ for $24 \mathrm{~h}$. Quality analyses of different samples were carried out over 30 consecutive days, during $1 \mathrm{~d}, 4 \mathrm{~d}$, and $30 \mathrm{~d}$ of storage. Thirty fruit samples were taken from a closed container at each sampling date.

\subsection{Colour Measurement}

The Minolta CR-400 Chroma Meter (Minolta Corp., Osaka, Japan) was used to obtain fruit skin colour from three different locations around the equator of the fruit. The colour was recorded using $a^{*}$ and $b^{*}$ scale, where $a^{*}$ represents the colour between green $\left(-a^{*}\right)$, and red $\left(+a^{*}\right)$ and $b^{*}$ represents the colour between blue $\left(-b^{*}\right)$ and yellow $\left(+b^{*}\right)$. The $a^{*}$ and $b^{*}$ values were converted into Hue angle $\left[\mathrm{H}=\tan ^{-1}\left(b^{*} / a^{*}\right)\right]$. Three replicates at each period were performed for each analysis.

\subsection{Respiratory Rate and Decay Rate}

Respiration rate of citrus fruit was determined, referring to the method of Huang and Jiang [27]. Four whole citrus fruits were weighed and sealed into a plastic box that connected the $\mathrm{CO}_{2} / \mathrm{H}_{2} \mathrm{O}$ Analyzer (LI-6262, LI COR, USA) before the amount of $\mathrm{CO}_{2}$ was recorded for $5 \mathrm{~min}$. Respiration rates were expressed as the rate of $\mathrm{CO}_{2}$ production as calculated on a fresh weight basis $\left(\mathrm{mg} \times \mathrm{kg}^{-1} \times \mathrm{s}^{-1}\right)$.

During the course of the experiment, the number of fruits showing decay symptoms was visually estimated. Fruits with visible mould growth were considered to be rotted, and the percentage of decayed fruits was expressed as the decay rate.

\subsection{Sample Preparation}

Sample powder of fruit peel was extracted with $10 \mathrm{~mL}$ of $70 \%$ methanol for $30 \mathrm{~min}$ by ultrasonic extraction. The extracting solution was subsequently centrifuged at $3000 \times g$ for $10 \mathrm{~min}$, and the residue was extracted again in the same way. It was then passed through a $0.2 \mu \mathrm{m}$ membrane filter and stored at $4{ }^{\circ} \mathrm{C}$ before analysis. 


\subsection{Antioxidant Activity Assay}

The antioxidant activity was evaluated by DPPH (2,2-diphenyl-1-picrylhydrazyl) and ABTS (2,2' -azino-bis(3-ethylbenzthiazoline-6-sulphoic acid) methods. The scavenging activity on DPPH radical was determined according to the method of Yang et al. [28] with some modifications. $0.4 \mathrm{~mL}$ of the diluted sample extracting solution was mixed with $3.5 \mathrm{~mL}$ of $0.12 \mathrm{mM}$ DPPH solution in methanol. The absorbance was measured at $517 \mathrm{~nm}$. The ABTS assay was measured according to the method established in the literature [29]. The ABTS ${ }^{+}$working solution was prepared by diluting the stock solution accurately with sodium acetate buffer to obtain an absorbance of $0.70 \pm 0.01$ at $734 \mathrm{~nm}$. $0.4 \mathrm{~mL}$ of the diluted samples were added to $3.6 \mathrm{~mL}$ of the $\mathrm{ABTS}^{+}$working solution, having reacted for $30 \mathrm{~min}$ at room temperature. The results were calculated as mmol Trolox $\mathrm{TE} \times \mathrm{kg}^{-1}$ dry weight.

\subsection{Instrumentation and Chromatographic Conditions}

Acquity ultra-performance liquid chromatography (UPLC) ${ }^{\circledR} \mathrm{H}-\mathrm{Class}$ (Waters, MA, USA) and a BEH C18 column $(1.7 \mu \mathrm{m}, 2.1 \mathrm{~mm} \times 50 \mathrm{~mm})$ were used to separate and quantitate the flavonoid in citrus peel samples. The binary mobile phase consisted of $0.5 \%$ aqueous formic acid (A) and HPLC grade methanol (B). A gradient elution at a flow rate of $0.3 \mathrm{~mL} \mathrm{~min}^{-1}$ was employed as follows: $5 \% \mathrm{~B}$ at $0-7 \mathrm{~min}, 5-12 \% \mathrm{~B}$ at $7-8 \mathrm{~min}, 12-17 \% \mathrm{~B}$ at $8-12 \mathrm{~min}, 17 \% \mathrm{~B}$ at $12-17 \mathrm{~min}, 17-30 \% \mathrm{~B}$ at $17-18 \mathrm{~min}, 30 \% \mathrm{~B}$ at $18-26 \mathrm{~min}, 30-70 \% \mathrm{~B}$ at $26-42 \mathrm{~min}$ and $70-5 \% \mathrm{~B}$ at $42-45 \mathrm{~min}$. Eleven flavonoid standard references were purchased from Chengdu Must Bio-Technology Corp. (Chengdu, China, purity >98\%).

\section{8. q-PCR Analysis}

Total RNA was isolated from $5 \mathrm{~g}$ of frozen skin tissue powder using TriZol Reagent (Invitrogen, USA) and then treated with DNase I at $37^{\circ} \mathrm{C}$ for $1 \mathrm{~h}$ to eliminate genomic DNA contamination. The first-strand cDNA was synthesized from $1 \mu \mathrm{g}$ of total RNA using a PrimeScript ${ }^{\circledR} \mathrm{RT}$ reagent kit with gDNA eraser (TAKARA-RR036A, Dalian, China). The cDNA was diluted 10-fold, and $2 \mu \mathrm{L}$ of the diluted cDNA was used as the template for q-PCR analysis.

The quantitative real-time PCR (q-PCR) experiment was performed on the Step One Plus ${ }^{\mathrm{TM}}$ (Applied Biosystems, Foster City, CA, USA). Fluorescent intensity data were analysed by 7500 Fast System Software 2.0.1. The q-PCR assay was performed under the following parameters: $95^{\circ} \mathrm{C}$ for $5 \mathrm{~min}, 40$ cycles at $95^{\circ} \mathrm{C}$ for $5 \mathrm{~s}, 60^{\circ} \mathrm{C}$ for $5 \mathrm{~s}$, and $72{ }^{\circ} \mathrm{C}$ for $34 \mathrm{~s}$. The $2^{-\Delta \Delta \mathrm{CT}}$ method was used to calculate the transcript values relative to the endogenous actin gene.

Chalcone synthase $(\mathrm{CHS})$ and chalcone isomerase $(\mathrm{CHI})$ gene-specific primers were designed on the sequences reported by Wang et al. [30]. Chitinase $(C H T)$, phenylalanine ammonia-lyase $(P A L)$, and $\beta$-1,3-glucanase (GLU) gene-specific primers were designed on the sequences reported by Lu et al. [31].

\subsection{Statistical Analysis}

All data analyzed were presented as the mean \pm standard deviation (SD) and were subjected to analysis of variance (ANOVA). To compare the mean differences, the effect of ozone treatment and duration on fruit quality (respiratory, fruit colour, and decay) and the content of flavonoid in fruit peel extract and their antioxidant capacity were evaluated by Duncan's multiple range tests $(p<0.05)$. Differences resulting in $p$-values of less than 0.05 were considered to be statistically significant.

\section{Results and Discussion}

\subsection{Physical and Physiological Analyses}

During postharvest storage (Table 1), the respiration rate of ozone treatment was lower than the control check (CK). The respiration rate of the $4 \mathrm{~d}$ fruit was similar to that of $30 \mathrm{~d}$ fruit following ozone-treated fruit. The results indicate that the ozone treatment can reduce the respiration rate at the 
earlier storage stage and inhibit the increased respiratory rate of fruit at the later storage stage, and thus reduce the nutrition loss in fruit.

Table 1. The respiration rate, hue angle value $\left(\mathrm{Hue}^{0}\right)$ and decay rate of mandarin citrus fruit. Each value is presented as a mean \pm standard deviation $(n=3)$. Values in the rows denoted with different superscript letters (a-f) indicate significant differences at $p<0.05$.

\begin{tabular}{|c|c|c|c|c|c|c|}
\hline & CK-1 d & $\mathrm{O}_{3}-1 \mathrm{~d}$ & CK-4 d & $\mathrm{O}_{3}-4 \mathrm{~d}$ & CK-30 d & $\mathrm{O}_{3}-30 \mathrm{~d}$ \\
\hline $\begin{array}{l}\text { Respiratory rate } \\
\left(\mathrm{mg} \times \mathrm{kg}^{-1} \times \mathrm{s}^{-1}\right)\end{array}$ & $16.2^{\mathrm{a}} \pm 1.5$ & $12.2^{b} \pm 0.8$ & $10.2^{\mathrm{c}} \pm 1.10$ & $8.4^{\mathrm{d}} \pm 0.7$ & $15.7^{\mathrm{a}} \pm 4.89$ & $8.2^{\mathrm{d}} \pm 3.9$ \\
\hline Hue $^{0}$ & $98.3^{a} \pm 3.3$ & $104.7^{\mathrm{b}} \pm 4.0$ & $87.2^{c} \pm 2.9$ & $100.7^{\mathrm{d}} \pm 5.4$ & $76.0^{\mathrm{e}} \pm 2.7$ & $79.2^{\mathrm{f}} \pm 3.9$ \\
\hline Decay rate $(\%)$ & - & - & - & - & $34.7^{\mathrm{a}}$ & $14.0^{\mathrm{b}}$ \\
\hline
\end{tabular}

Hue index is the most commonly used parameter to indicate the colour changes of citrus fruit in storage. Table 1 shows CIELab color parameters of postharvest citrus fruits at the end of the storage process. The Hue angle value of fruit treated by ozone was significantly higher (less yellow) than those untreated. Changes in hue resulting from ozone treatment became very small by 30 days. The results demonstrated that lower maturity and degradation of chlorophyll and better keeping green effects were obtained with ozone treatment.

By statistical analysis (Table 1), the rotting rate after treatment were $14.0 \%$ during the storage of $30 \mathrm{~d}$, the rotting rate lower than the $\mathrm{CK}$ of $34.7 \%$. The results indicated that ozone treatment could decrease the rate of fruit rot.

\subsection{Effects of Ozone on the Flavonoids Content of Citrus Peel}

The content of flavonoid in the samples was determined by the established method [32]. The chromatogram is shown in Figure 1; good separation of the flavonoid can be achieved in mixed standards and samples.

The effects of ozone treatment on the flavonoid content of mandarin citrus peel are shown in Table 2. In the peel of mandarin citrus, the content of nine flavonoid compounds except naringin and neohesperidin were detected and analysed. During the storage and ozone treatment period, the content of narirutin, hesperidin, and rutin displayed an increasing trend. Hesperidin and narirutin were found to be the major compounds. Similar results for mandarin citrus by UV radiation have been reported by Shen et al. [32]. In our research, upon exposure to ozone for 1 day, the total flavonoid content of the samples increased significantly $(p<0.05)$ by $5.8 \%$. The flavonoid content of $4 \mathrm{~d}$ and $30 \mathrm{~d}$ increased significantly by $10.8 \%$ and $11.3 \%$, respectively.

Remarkably, the ozone treatment leads to the result that the flavonoid accumulation patterns of different branches changed significantly. During $4 \mathrm{~d}$ and $30 \mathrm{~d}$, narirutin content was increased by $27.3 \%$ and $29.9 \%$, respectively, as compared to the control, and for hesperidin, the increment caused by the ozone treatment were $2.88 \%$ and $5.75 \%$, respectively. For the content of four main flavanone glycosides (FGs) including narirutin, hesperidin, taxifolin and didymin on $4 \mathrm{~d}$, the control fruits were 6527.7 $\pm 32.6,15644.2 \pm 263.8,135.2 \pm 2.2$ and $1255.7 \pm 1.7 \mathrm{mg} \times \mathrm{kg}^{-1}$, while the ozone-treated fruits were $8306.2 \pm 102.4,16095.1 \pm 81.1,149.9 \pm 4.7$ and $1635.3 \pm 2.3 \mathrm{mg} \times \mathrm{kg}^{-1}$, indicating a general enhanced tendency of FGs in Satsuma mandarin fruits treated with ozone. The levels of the three determined polymethoxylated flavones (PMFs, sinensentin, nobiletin, and tangeretin) declined significantly in the ozone-treated fruits. The content of sinensentin, nobiletin, and tangeretin were 478.6 $\pm 20.1,759.9 \pm$ 13.9 and $313.8 \pm 4.3 \mathrm{mg} \times \mathrm{kg}^{-1}$ in ozone treated fruits on $30 \mathrm{~d}$, while they were $398.4 \pm 5.1,653.8 \pm 1.5$ and $307.1 \pm 3.4 \mathrm{mg} \times \mathrm{kg}^{-1}$ for CK on $30 \mathrm{~d}$, respectively. For rutin, which was the only determined flavonol glycoside, the increment caused by the ozone treatment on $4 \mathrm{~d}$ and $30 \mathrm{~d}$ were $5.9 \%$ and $22.8 \%$, respectively. For diosmetin, as the only flavone, the content first rose and then took a downward trend afterward. 

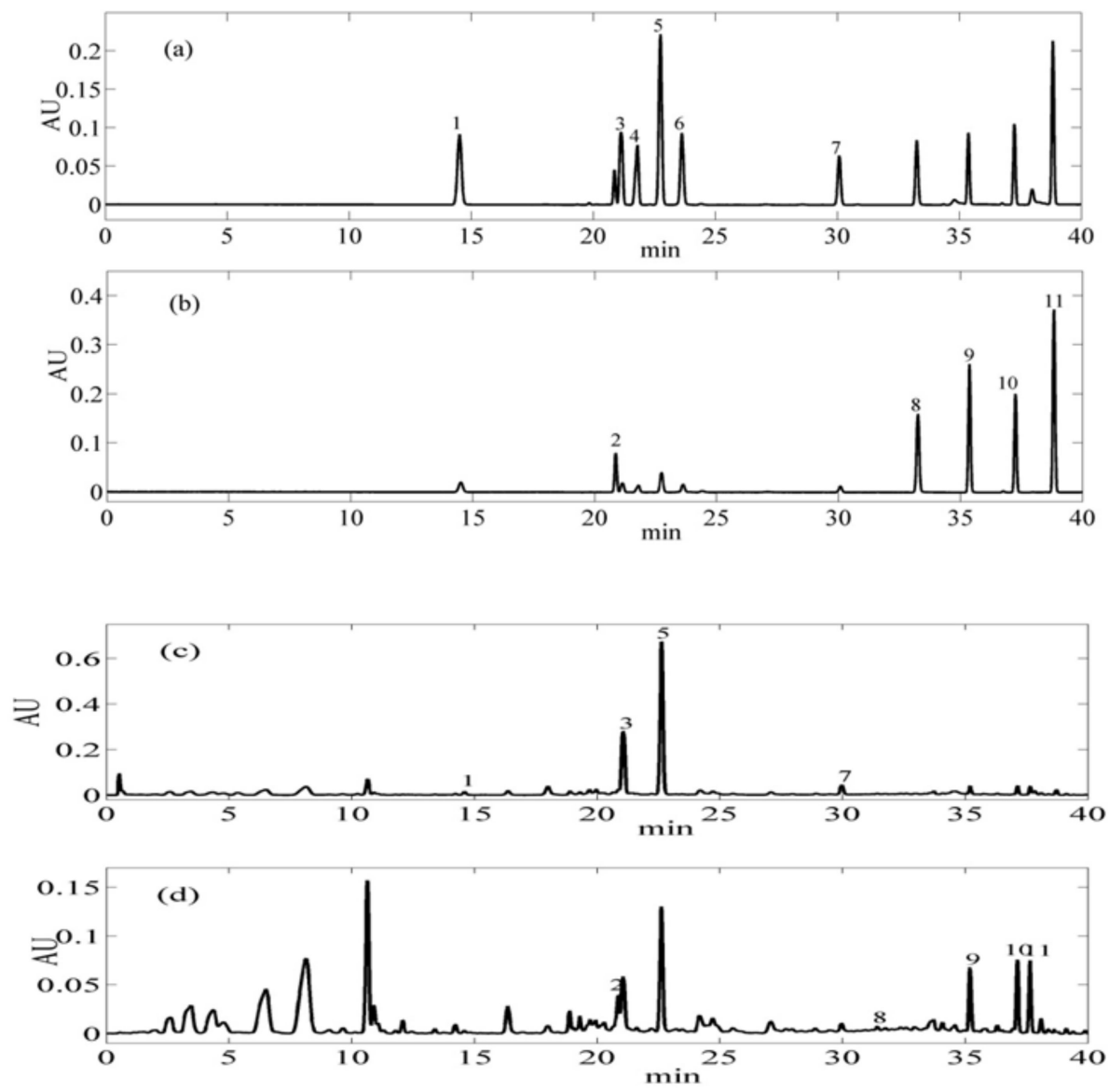

Figure 1. Ultra-high performance liquid chromatography (UPLC) chromatograms of eleven flavonoid mixed standards and citrus mandarin peel samples at $280 \mathrm{~nm}$ and $330 \mathrm{~nm}$. (a) The mixed standard of naringin, narirutin, hesperidin, neohesperidin, taxifolin, didymin at $280 \mathrm{~nm}$; (b) The mixed standard of rutin, diosmetin, sinensetin, nobiletin, and tangeretin at $330 \mathrm{~nm}$; (c) Sample of narirutin, hesperidin, taxifolin, didymin at $280 \mathrm{~nm}$; (d) Sample of rutin, diosmetin, sinensetin, nobiletin, and tangeretin at $330 \mathrm{~nm}$.

Table 2. The flavonoid content $\left(\mathrm{mg} \times \mathrm{kg}^{-1}\right.$ dry weight) in the peel of mandarin citrus. Each value is presented as a mean \pm standard deviation $(n=3)$. Values in the rows denoted with different superscript letters $(\mathrm{a}-\mathrm{f})$ indicate significant differences at $p<0.05$.

\begin{tabular}{|c|c|c|c|c|c|c|}
\hline & CK-1d & $\mathrm{O}_{3}-1 \mathrm{~d}$ & CK-4d & $\mathrm{O}_{3}-4 \mathrm{~d}$ & CK-30d & $\mathrm{O}_{3}-30 \mathrm{~d}$ \\
\hline Naringin & - & - & - & - & - & - \\
\hline Narirutin & $7661.8^{\mathrm{a}} \pm 79.5$ & $6599.2^{b c} \pm 102.9$ & $6527.7^{b} \pm 32.6$ & $8306.2^{\mathrm{d}} \pm 102.4$ & $6689.1^{\mathrm{c}} \pm 34.2$ & $8686.6^{\mathrm{e}} \pm 92.3$ \\
\hline Hesperidin & $13,136.6^{\mathrm{a}} \pm 144.0$ & $14,851.7^{b} \pm 275.2$ & $15,644.2^{c} \pm 263.8$ & $16,095.1^{\mathrm{d}} \pm 81.1$ & $15,623.4^{c} \pm 59.5$ & $16,522.2^{\mathrm{e}} \pm 159.8$ \\
\hline Taxifolin & $119.7^{\mathrm{a}} \pm 0.8$ & $136.6^{b} \pm 0.3$ & $135.2^{b} \pm 2.2$ & $149.9^{\mathrm{c}} \pm 4.7$ & $145.6^{c} \pm 5.2$ & $136.5^{b} \pm 2.3$ \\
\hline Didymin & $1355.8^{a} \pm 0.6$ & $1311.4^{\mathrm{a}} \pm 4.3$ & $1255.7^{\mathrm{b}} \pm 1.7$ & $1635.3^{c} \pm 2.3$ & $1584.9^{\mathrm{d}} \pm 86.6$ & $1521.5^{\mathrm{e}} \pm 13.5$ \\
\hline Rutin & $1765.8^{\mathrm{a}} \pm 39.5$ & $2583.8^{\mathrm{bd}} \pm 83.8$ & $2473.5^{c} \pm 86.8$ & $2619.6^{\mathrm{d}} \pm 46.5$ & $2499.4^{b c} \pm 24.8$ & $3068.7^{\mathrm{e}} \pm 15.3$ \\
\hline Sinensetin & $464.6^{\mathrm{ab}} \pm 20.6$ & $469.8^{\mathrm{abc}} \pm 9.1$ & $446.7^{a} \pm 15.3$ & $494.8^{c} \pm 11.8$ & $478.6^{b c} \pm 20.1$ & $398.4^{d} \pm 2.9$ \\
\hline Nobiletin & $626.9^{\mathrm{a}} \pm 8.0$ & $645.6^{\mathrm{ac}} \pm 2.2$ & $628.6^{\mathrm{ac}} \pm 6.3$ & $728.2^{b} \pm 9.8$ & $759.9^{b} \pm 13.9$ & $653.8^{c} \pm 1.5$ \\
\hline Tangeretin & $311.4^{\mathrm{a}} \pm 7.2$ & $294.9^{b} \pm 2.9$ & $292.2^{b} \pm 1.0$ & $309.6^{\mathrm{a}} \pm 2.1$ & $313.8^{\mathrm{a}} \pm 4.3$ & $307.1^{\mathrm{a}} \pm 3.4$ \\
\hline Total & $25,510.1^{\mathrm{a}} \pm 302.0$ & $26,979.8^{b} \pm 483.0$ & $27,484.9^{\mathrm{c}} \pm 409.8$ & $30,439.7^{\mathrm{d}} \pm 260.8$ & $28,194.7^{\mathrm{e}} \pm 251.7$ & $31,366.3^{f} \pm 292.0$ \\
\hline
\end{tabular}

\subsection{Analysis of Antioxidant Capacity}

The antioxidant activity of plant extracts was not be evaluated by using only one method due to the complexity of chemical composition and oxidative stress [33]. Therefore, DPPH and ABTS methods were used to evaluate the antioxidant activity in this study (Table 3). 
Table 3. The Results of 2,2-diphenyl-1-picrylhydrazyl (DPPH) and 2,2'-azino-bis(3-ethylbenzthiazoline6-sulphoic acid (ABTS) free radical scavenging activity (mmol Trolox TE $\times \mathrm{kg}^{-1}$ dry weight) in the peel of mandarin citrus. Each value is presented as a mean \pm standard deviation $(n=3)$. Values in the rows denoted with different superscript letters $(\mathrm{a}-\mathrm{d})$ indicate significant differences at $p<0.05$.

\begin{tabular}{ccccccc}
\hline & CK-1d & $\mathbf{O}_{3}-\mathbf{- 1 d}$ & CK-4d & $\mathbf{O}_{3}-4 d$ & CK-30d & $\mathbf{O}_{3}-30 d$ \\
\hline DPPH & $44.0^{\mathrm{a}} \pm 0.2$ & $47.6^{\mathrm{b}} \pm 0.2$ & $47.4^{\mathrm{b}} \pm 0.1$ & $51.4^{\mathrm{c}} \pm 0.3$ & $50.9^{\mathrm{c}} \pm 0.8$ & $52.7^{\mathrm{d}} \pm 0.2$ \\
ABTS & $113.3^{\mathrm{a}} \pm 1.3$ & $118.0^{\mathrm{b}} \pm 0.4$ & $119.0^{\mathrm{b}} \pm 0.4$ & $121.9^{\mathrm{c}} \pm 0.4$ & $124.1^{\mathrm{d}} \pm 1.8$ & $125.4^{\mathrm{d}} \pm 0.1$ \\
\hline
\end{tabular}

The antioxidant activity of citrus fruit peel, as estimated by the DPPH assay, increased with ozone treatment. Upon exposure to ozone on $1 \mathrm{~d}$ and $4 \mathrm{~d}$, the antioxidant activity of citrus peel extract increased $(p<0.05)$ by $8.7 \%$ and $8.5 \%$, respectively. While on $30 \mathrm{~d}$ of storage, the DPPH assays of ozone-treated fruit peel only showed a slight increase of $3.1 \%$. On the other hand, when the antioxidant activity of citrus fruit peel was determined with the ABTS method, compared to control fruit, a slight increase of $4.2 \%, 2.1 \%$, and $1.5 \%$ were measured on $1 \mathrm{~d}, 4 \mathrm{~d}$, and $30 \mathrm{~d}$, respectively. The trend obtained from both DPPH and ABTS assays was similar to that of total flavonoids, so it can be deduced that flavonoids compounds are major antioxidants in citrus peel.

\subsection{Gene Expression Involved in Flavonoid Synthesis}

To understand the molecular mechanism of the differences observed in antioxidant activity changes and flavonoid accumulation following ozone fumigation, expression of $C H S, C H I, G L U, P A L$, CHT, and POD were analysed by q-PCR. The results are shown in Figure 2. The q-PCR analysis was carried out on citrus peel samples collected on $1 \mathrm{~d}, 4 \mathrm{~d}$ and $30 \mathrm{~d}$, due to the correspondence between ozone fumigation and antioxidant activity and flavonoid content at those time points.

Significant upregulations in $\mathrm{CHS}$ and $\mathrm{CHI}$ levels were observed in the treated citrus peel. The mRNA levels of CHS were increased by 3.0- and 3.4-fold in ozone-treated on $4 \mathrm{~d}$ and $30 \mathrm{~d}$. The levels of $\mathrm{CHI}$ transcripts in ozone treated citrus peel showed an increment on day 4, with the highest induction of an 11.1-fold increase observed on $30 \mathrm{~d}$. The expression of the GLU gene in the treated peel samples reached the highest level after $1 \mathrm{~d}$ storage and then declined on $4 \mathrm{~d}$ and $30 \mathrm{~d}$. However, the overall gene expression levels in samples obtained from ozone treatment were significantly higher than the levels observed in the control citrus fruit peel. The treatment of Satsuma mandarin with ozone maintained the increases in $C H T$ and $P A L$ mRNA transcripts during different storage periods. The expressions of CHT were 2.1, 4.8, and 6.2-fold, and the expressions of PAL were 9.0-, 2.6-, and 3.0-fold higher than in the controls on $1 \mathrm{~d}, 4 \mathrm{~d}$, and $30 \mathrm{~d}$, respectively.

\subsection{Gene Expression of POD}

The expression of $P O D$ in the citrus peel was affected significantly by the ozone treatment. Although the $P O D$ transcripts in the ozone-treated mandarin peel decreased on the first day after postharvest, the treatment of Satsuma mandarin with ozone-induced $P O D$ transcription, as shown by an approximately 4.9-fold increase on $4 \mathrm{~d}$ and was 9.2-fold higher on $30 \mathrm{~d}$ than the control, respectively. The expression of $P O D$ was rapidly increased in ozone treatment during storage, and the higher expression of $P O D$ in the ozone-treated citrus fruit would favour protecting against the cell membrane damage. 

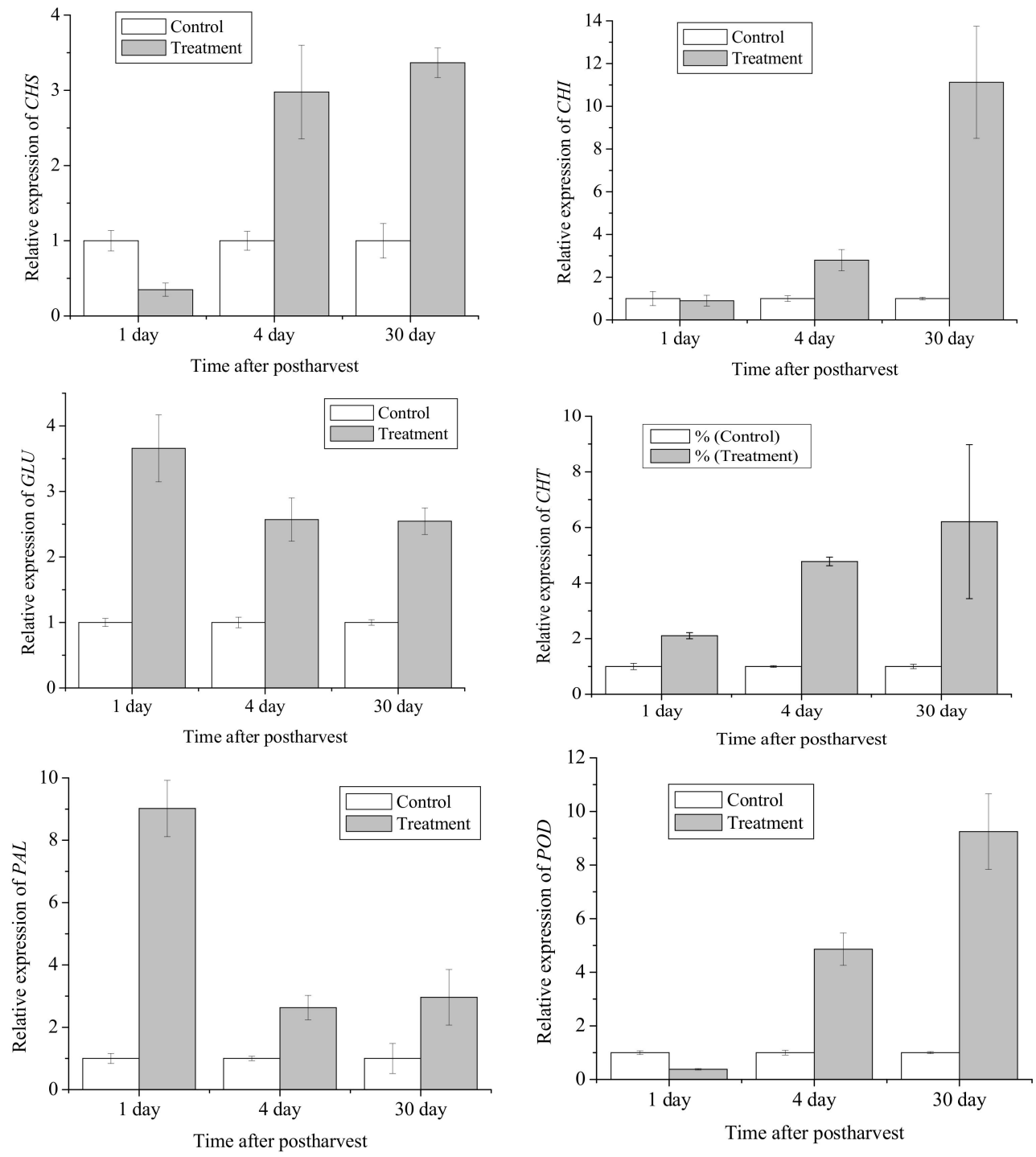

Figure 2. Expression patterns of six genes determined by q-PCR in the skin of citrus mandarin peel. Each data point represents a mean \pm standard error $(n=3)$.

\section{Discussion}

The respiration rate of citrus fruit is an important index reflecting the effect of metabolism after storage. Our study indicated that ozonation could inhibit the respiration of postharvest Satsuma mandarin, and the reason is that ozone triggers the formation of reactive oxygen species (ROS), which lead to stomata closure [34]. Similar results were obtained by other investigators. Zhang et al. [35] showed that ozonated water treatment caused much reduction in respiration rates of fresh-cut celery. Chauhan et al. [36] found that respiration rates of carrot sticks washed by ozonated water were significantly lower than that of non-treated after $30 \mathrm{~d}$ of controlled atmosphere storage.

Colour changes have been used to assess postharvest fruit senescence by ozone treatment. Zambre et al. [37] observed that the development of red colour was delayed during shelf-life storage of tomatoes treated by gaseous ozone. Sandhu et al. [38] reported that ozone could react with carotenoids consisting of the multiple conjugated double bonds in wheat flour, thereby decreasing $b^{*}$-value (yellowness). Bermudez-Aguirre and Barbosa-Canovas [39] treated carrots with ozone gas at concentrations between 10 and $115 \mathrm{mg} \times \mathrm{L}^{-1}$, the lightness value $\left(\mathrm{L}^{*}\right)$ were significantly increased, which suggests that the orange-red peel color was bleached by the ozone treatment. Our results showed that treatment with ozone could maintain the original quality of the citrus fruit regarding its color characteristics. 
Based on the effect of ozone treatment on quality and physiological parameters, our study demonstrated that the antioxidant activity of Satsuma mandarin peel increased as fruit storage time increased and was further enhanced by exposure to ozone from $1 \mathrm{~d}$ to $30 \mathrm{~d}$. The antioxidant capacity increased when total flavonoids (TF) content increased, and this was expected because there was a highly significant correlation between antioxidant capacity and TF. The correlation coefficients between DPPH/ABTS and TF were 0.93 and 0.86, respectively. Yeoh and his colleagues [18] obtained similar results in a study of the antioxidant activity measured by DPPH and ferric reducing ability of plasma (FRAP) assays of fresh-cut papaya. Antioxidant activity increased significantly $(p<0.05)$ after exposure to $9.2 \mu \mathrm{l} \times \mathrm{L}^{-1}$ of ozone.

Flavonoids have been shown to be the major contributors to the scavenging of oxygen-derived free radicals in plant-derived food $[40,41]$. Studied have reported a positive correlation between the antioxidant capacity and flavonoid content [42,43]. The DPPH and ABTS free radical scavenging activity of fruit directly correlated with the prevention of fruit senescence and quality during storage [44,45]. Certain bioactive compounds, i.e., flavonoid concentrations, are the primary reason for the higher DPPH and ABTS scavenging capacity of fruit [46]. An increase in antioxidant activity after continuous exposure to gaseous ozone may be due to the activation of several intracellular enzymes that are responsible for the control of endogenous antioxidant defence in harvested fruits and vegetables [47].

Flavonoids are able to act as antioxidants, and their antioxidant potential is determined by their chemical structure [48]. Mandarin is rich in hesperidin, followed by narirutin [49,50]. Hesperidin shows high antioxidant activities, while that of narirutin is about ten times less efficient [51]. Indeed, the antioxidant activity of hesperidin is explained by the presence of methoxy $\left(-\mathrm{OCH}_{3}\right)$ and hydroxyl $(-\mathrm{OH})$ groups in the B ring. These two kinds of organic functional groups have free radical scavenging and antioxidant activity comparable to the one observed due to the existence of a catechol group. In contrast, narirutin contains only one hydroxyl group in the B ring. Therefore, antioxidant activity is much lower [52]. Our UPLC analysis showed that the flavonoid composition of mandarin peel following ozone treatment is characterized by the presence of high-level hesperidin at the end of storage.

The expression of CHS and CHI genes was significantly correlated to flavonoid accumulation in the fruit peels during postharvest storage and ozone treatment of Satsuma mandarin $(\mathrm{r}=0.99$ for $\mathrm{CHS}$ and 0.78 for $\mathrm{CHI}$ ). It was consistent with previous studies examining UV-B treatment of peach [53] and fruit development using Rio Red grapefruit peels [54]. Meanwhile, expression of both genes was correlated with the content of narirutin and hesperidin, and the correlation coefficients between gene expression and accumulation of the above two dominant flavonoids had a range of 0.73-0.99. A similar result was also observed in Wang's study [30]: total flavonoid, narirutin, and hesperidin content, as well as expression of CHS and CHI genes, decreased gradually in the peels of Satsuma mandarin during fruit maturation.

GLU and CHT have the ability to directly hydrolyse fungal cell walls in plant pathogens, thereby releasing $\beta$-1, 3-glucan, and chitin, which then trigger host defence responses [31]. PAL is involved in the biosynthesis of flavonoids of citrus fruit and could be stimulated by various abiotic stresses such as wounding, infection, and UV-C exposure [53]. In the current study, GLU, CHT and PAL transcript expression increased in Satsuma mandarin peels treated with ozone during storage, and these values were significantly higher than that in control fruits. Moreover, the level of total flavonoids increased and was significantly higher in ozone-treated fruits when compared to control after $4 \mathrm{~d}$ and $30 \mathrm{~d}$ of storage. It is proposed that the inductive effect of ozone on the defense-related flavonoid compounds in Satsuma mandarin contributed to the observed resistance to fruit decay symptoms when they started to appear. Similar biostimulant activities by ozone have also been reported in other horticultural crops. Ozone elicits the accumulation of pathogenesis-related (PR) proteins GLU and POD in kiwi fruit postharvest ripening $[55,56]$. Ozone also induced and elevated the gene expression of GLU, CHT and $P A L$ in 'Redglobe' and 'Sugraone' table grapes [57], and thus, inhibited the development of postharvest fungal decay. 
Increased $P O D$ activity was related to enhanced plant disease resistance [58]. In addition, $P O D$ was related to the accumulation of flavonoid and phenolic compounds. The results showed that ozone treatment induced higher gene expression levels of $P O D$ during the latter storage period, corresponding to the total flavonoid content which was significantly higher than that of the control over the same period, suggesting that in harvested Satsuma mandarin fruits, the increased expression of POD gene by ozone treatment was correlated to the levels of total flavonoids. Similarly, Sachadyn-Król et al. [59] found that the POD activities were higher in pepper fruit treated with gaseous ozone when compared to that in control samples. The activities of $P O D$ and $P A L$ were higher in ozone fumigated papaya fruit than in untreated fruit after 14 days of storage [60]. These results also suggest that ozone treatment enhanced expression of $P O D$, and this contributed to the activation of the antioxidant defence system in Satsuma mandarin fruits.

\section{Conclusions}

Continuous exposure of Satsuma mandarin fruits to ozone resulted in retarded respiration rate, reduced rot rate, and better appearance. The results indicate that fumigation with the ozone-induced changes in postharvest Satsuma mandarin is an effective strategy to regulate the concentration of flavonoid compounds, and it is able to induce changes in gene expression level and increase both DPPH and ABTS values. The application of ozone seems to be a feasible solution to reduce quality loss during the storage of Satsuma mandarin.

Author Contributions: Conceptualization-Y.J. and Y.S.; methodology-C.Y., J.J., and G.L.; Writing-Original Draft preparation-X.Z.

Funding: This research was funded by the National Key Research and Development Program of China (2017YFD0401301), the Special Project of Changsha-Zhuzhou-Xiangtan Independent Innovation Demonstration Zones (2018XK2006), and Science and Technology Innovation Projects of Hunan Academy of Agricultural Sciences (2018 ZD04-1, 2017JC67, and 2019TD04).

Acknowledgments: We thank South China Botanical Garden for their assistance in sample experimental platform.

Conflicts of Interest: The authors declare no conflict of interest.

\section{References}

1. Askarne, L.; Talibi, I.; Boubaker, H.; Boudyach, E.H.; Msanda, F.; Saadi, B.; Serghini, M.A.; Ait Ben Aoumar, A. In vitro and in vivo antifungal activity of several Moroccan plants against Penicillium italicum, the causal agent of citrus blue mold. Crop Prot. 2012, 40, 53-58. [CrossRef]

2. Hao, W.N.; Zhong, G.H.; Hu, M.Y.; Luo, J.J.; Weng, Q.F.; Rizwan-ul-Haq, M. Control of citrus postharvest green and blue mold and sour rot by tea saponin combined with imazalil and prochloraz. Postharvest Biol. Technol. 2010, 56, 39-43. [CrossRef]

3. Duan, X.F.; Jing, G.X.; Fan, F.; Tao, N.G. Control of postharvest green and blue molds of citrus fruit by application of sodium dehydroacetate. Postharvest Biol. Technol. 2016, 113, 17-19. [CrossRef]

4. Tzortzakis, N.G.; Singleton, I.; Barnes, J. Deployment of low-level ozone-enrichment for the preservation of chilled fresh produce. Postharvest Biol. Technol. 2007, 43, 261-270. [CrossRef]

5. Guzel-Seydim, Z.B.; Greene, A.K.; Seydim, A.C. Use of ozone in the food industry. LWT Food Sci. Technol. 2004, 37, 453-460. [CrossRef]

6. Ali, A.; Ong, M.K.; Forney, C.F. Effect of ozone pre-conditioning on quality and antioxidant capacity of papaya fruit during ambient storage. Food Chem. 2014, 142, 19-26. [CrossRef]

7. Botondi, R.; De, S.F.; Moscatelli, N.; Vettraino, A.M.; Catelli, C.; Mencarelli, F. Ozone fumigation for safety and quality of wine grapes in postharvest dehydration. Food Chem. 2015, 188, 641-647. [CrossRef]

8. Han, Q.; Gao, H.Y.; Chen, H.J.; Fang, X.J.; Wu, W.J. Precooling and ozone treatments affects postharvest quality of black mulberry (Morus nigra) fruits. Food Chem. 2017, 221, 1947-1953. [CrossRef]

9. Tabakoglu, N.; Karaca, H. Effects of ozone-enriched storage atmosphere on postharvest quality of black mulberry fruits (Morus nigra L.). LWT Food Sci. Technol. 2018, 92, 276-281. [CrossRef] 
10. Glowacz, M.; Colgan, R.; Rees, D. Influence of continuous exposure to gaseous ozone on the quality of red bell peppers, cucumbers and zucchini. Postharvest Biol. Technol. 2015, 99, 1-8. [CrossRef]

11. Contigiani, E.V.; Jaramillo-Sánchez, G.; Castro, M.A.; Gómez, P.L.; Alzamora, S.M. Postharvest quality of strawberry fruit (Fragaria $x$ ananassa Duch cv. Albion) as affected by ozone washing: Fungal spoilage, mechanical properties, and structure. Food Bioprocess. Technol. 2018, 11, 1639-1650. [CrossRef]

12. Artés-Hernández, F.; Artes, F.; Tomas-Barberan, F.A. Quality and enhancement of bioactive phenolics in cv. Napoleon table grapes exposed to different postharvest gaseous treatments. J. Agric. Food Chem. 2003, 51, 5290-5295. [CrossRef]

13. Zhao, Z.; Xu, G.M.; Han, Z.N.; Li, Q.Q.; Chen, Y.L.; Li, D.P. Effect of ozone on the antioxidant capacity of “Qiushui" pear (Pyrus pyrifolia Nakai cv. Qiushui) during postharvest storage. J. Food Qual. 2013, 36, 190-197. [CrossRef]

14. Singla, R.; Ganguli, A.; Ghosh, M. An effective combined treatment using malic acid and ozone inhibits Shigella spp. on sprouts. Food Control 2011, 22, 1032-1039. [CrossRef]

15. Boonkorn, P.; Gemma, H.; Sugaya, S.; Setha, S.; Uthaibutra, J.; Whangchai, K. Impact of high-dose, short periods of ozone exposure on green mold and antioxidant enzyme activity of tangerine fruit. Postharvest Biol. Technol. 2012, 67, 25-28. [CrossRef]

16. Lin, S.H.; Chen, C.K.; Luo, H.X.; Xu, W.T.; Zhang, H.J.; Tian, J.J.; Ju, R.H.; Wang, L.Q. The combined effect of ozone treatment and polyethylene packaging on postharvest quality and biodiversity of Toona sinensis (A.Juss.) M.Roem. Postharvest Biol. Technol. 2019, 154, 1-10. [CrossRef]

17. Alothman, M.; Kaur, B.; Fazilah, A.; Bhat, R.; Karim, A.A. Ozone-induced changes of antioxidant capacity of fresh-cut tropical fruits. Innov. Food Sci. Emerg. Technol. 2010, 11, 666-671. [CrossRef]

18. Yeoh, W.K.; Ali, A.; Forney, C.F. Effects of ozone on major antioxidants and microbial populations of fresh-cut papaya. Postharvest Biol. Technol. 2014, 89, 56-58. [CrossRef]

19. Goffi, V.; Zampella, L.; Forniti, R.; Petriccione, M.; Botondi, R. Effects of ozone postharvest treatment on physicochemical and qualitative traits of Actinidia chinensis 'Soreli' during cold storage. J. Sci. Food Agric. 2019, 99, 5654-5661. [CrossRef]

20. An, J.; Zhang, M.; Lu, Q. Changes in some quality indexes in freshcut green asparagus pretreated with aqueous ozone and subsequent modified atmosphere packaging. J. Food Eng. 2007, 78, 340-344. [CrossRef]

21. Lombardo, S.; Restuccia, C.; Pandino, G.; Licciardello, F.; Muratore, G.; Mauromicale, G. Influence of an $\mathrm{O}_{3}$-atmosphere storage on microbial growth and antioxidant contents of globe artichoke as affected by genotype and harvest time. Innov. Food Sci. Emerg. Technol. 2015, 27, 121-128. [CrossRef]

22. Chen, C.K.; Zhang, H.J.; Dong, C.H.; Ji, H.P.; Zhang, X.J.; Li, L.; Ban, Z.J.; Zhang, N.; Xue, W.T. Effect of ozone treatment on the phenylpropanoid biosynthesis of postharvest strawberries. RSC Adv. 2019, 9, 25429-25438. [CrossRef]

23. Luo, A.W.; Bai, J.Q.; Li, R.; Fang, Y.M.; Li, L.; Wang, D.; Zhang, L.; Liang, J.; Huang, T.Z.; Kou, L.P. Effects of ozone treatment on the quality of kiwifruit during postharvest storage affected by Botrytis cinerea and Penicillium. J. Phytopathol. 2019, 167, 470-478. [CrossRef]

24. Petriccione, M.; Pagano, L.; Forniti, R.; Zampella, L.; Mastrobuoni, F.; Scortichini, M.; Mencarelli, F. Postharvest treatment with chitosan affects the antioxidant metabolism and quality of wine grape during partial dehydration. Postharvest Biol. Technol. 2018, 137, 38-45. [CrossRef]

25. Zhou, D.; Wang, Z.; Tu, S.; Chen, S.; Peng, J.; Tu, K. Effects of cold plasma, UV or aqueous ozone treatment on Botrytis cinerea and their potential application in preserving blueberry. J. Appl. Microbiol. 2019, 127, 175-185. [CrossRef]

26. Modesti, M.; Petriccione, M.; Forniti, R.; Zampella, L.; Scortichini, M.; Mencarelli, F. Methyl jasmonate and ozone affect the antioxidant system and the quality of wine grape during postharvest partial dehydration. Food Res. Int. 2018, 112, 369-377. [CrossRef]

27. Huang, H.; Jiang, Y.M. Effect of plant growth regulators on banana fruit and broccoli during storage. Sci. Hortic. 2012, 145, 62-67. [CrossRef]

28. Yang, B.; Zhao, M.M.; Shi, J.; Yang, N.; Jiang, Y.M. Effect of ultrasonic treatment on the recovery and DPPH radical scavenging activity of polysaccharides from longan fruit pericarp. Food Chem. 2008, 106, 685-690. [CrossRef]

29. Re, R.; Pellegrini, N.; Proteggente, A.; Pannala, A.; Yang, M.; Rice-Evans, C. Antioxidant activity applying an improved ABTS radical cation decolorization assay. Free Radic. Bio. Med. 1999, 26, 1231-1237. [CrossRef] 
30. Wang, Y.; Li, J.; Xia, R.X. Expression of chalcone synthase and chalcone isomerase genes and accumulation of corresponding flavonoids during fruit maturation of Guoqing No. 4 satsuma mandarin (Citrus unshiu Marcow). Sci. Hortic. 2010, 125, 110-116. [CrossRef]

31. Lu, L.F.; Liu, Y.; Yang, J.L.; Azat, R.; Yu, T.; Zheng, X.D. Quaternary chitosan oligomers enhance resistance and biocontrolefficacy of Rhodosporidium paludigenum to green mold in satsuma orange. Carbohydr. Polym. 2014, 113, 174-181. [CrossRef] [PubMed]

32. Shen, Y.; Sun, Y.J.; Qiao, L.P.; Chen, J.C.; Liu, D.H.; Ye, X.Q. Effect of UV-C treatments on phenolic compounds and antioxidant capacity of minimally processed Satsuma mandarin during refrigerated storage. Postharvest Biol. Technol. 2013, 76, 50-57. [CrossRef]

33. Apak, R.; Güçlü, K.; Demirata, B.; Ozyürek, M.; Celik, S.E.; Bektaşoğlu, B.; Berker, K.; Ozyurt, D. Comparative evaluation of various total antioxidant capacity assays applied to phenolic compounds with the CUPRAC assay. Molecules 2007, 12, 1496-1547. [CrossRef] [PubMed]

34. Vahisalu, T.; Puzorjova, I.; Brosche, M.; Valk, E.; Lepiku, M.; Moldau, H.; Pechter, P.; Wang, Y.S.; Lindgren, O.; Salojärvi, J.; et al. Ozone-triggered rapid stomatal response involves the production of reactive oxygen species, and is controlled by SLAC1 and OST1. Plant. J. 2010, 62, 442-453. [CrossRef]

35. Zhang, L.K.; Lu, Z.X.; Yu, Z.F.; Gao, X. Preservation of fresh-cut celery by treatment of ozonated water. Food Control 2005, 16, 279-283. [CrossRef]

36. Chauhan, O.P.; Raju, P.S.; Ravi, N.; Singh, A.; Bawa, A.S. Effectiveness of ozone in combination with controlled atmosphere on quality characteristics including lignification of carrot sticks. J. Food Eng. 2011, 102, $43-48$. [CrossRef]

37. Zambre, S.S.; Venkatesh, K.V.; Shah, N.G. Tomato redness for assessing ozone treatment to extend the shelf life. J. Food Eng. 2010, 96, 463-468. [CrossRef]

38. Sandhu, H.P.S.; Manthey, F.A.; Simsek, S. Quality of bread made from ozonated wheat (Triticum aestivum L.) flour. J. Sci. Food Agric. 2011, 91, 1576-1584. [CrossRef]

39. Bermudez-Aguirre, D.; Barbosa-Canovas, G.V. Disinfection of selected vegetables under nonthermal treatments: Chlorine, acid citric, ultraviolet light and ozone. Food Control. 2013, 29, 82-90. [CrossRef]

40. Nijveldt, R.J.; Van Nood, E.; Van Hoorn, D.E.; Boelens, P.G.; Van Norren, K.; Van Leeuwen, P.A. Flavonoids: A review of probable mechanisms of action and potential applications. Am. J. Clin. Nutr. 2001, 74, 418-425. [CrossRef]

41. Maisuthisakul, P.; Suttajit, M.; Pongsawatmanit, R. Assessment of phenolic content and free radical-scavenging capacity of some Thai indigenous plants. Food Chem. 2007, 100, 1409-1418. [CrossRef]

42. Wang, C.; Chen, C.T.; Wang, S. Changes of flavonoid content and antioxidant capacity in blueberries after illumination with UV-C. Food Chem. 2009, 117, 426-431. [CrossRef]

43. Erkan, M.; Wang, S.Y.; Wang, C.Y. Effect of UV treatment on antioxidant capacity, antioxidant enzyme activity and decay in strawberry fruit. Postharvest Biol. Technol. 2008, 48, 163-171. [CrossRef]

44. Duan, X.W.; Liu, T.; Zhang, D.D.; Su, X.G.; Lin, H.T.; Jiang, Y.M. Effect of pure oxygen atmosphere on antioxidant enzyme and antioxidant activity of harvested litchi fruit during storage. Food Res. Int. 2011, 44, 1905-1911. [CrossRef]

45. Xi, Y.; Fan, X.G.; Zhao, H.D.; Li, X.H.; Cao, J.K.; Jiang, W.B. Postharvest fruit quality and antioxidants of nectarine fruit as influenced by chlorogenic acid. LWT-Food Sci. Technol. 2017, 75, 537-544. [CrossRef]

46. Carbone, K.; Mencarelli, F. Influence of short-term postharvest ozone treatments in nitrogen or air atmosphere on the metabolic response of white wine grapes. Food Bioprocess. Technol. 2015, 8, 1739-1749. [CrossRef]

47. González-Aguilar, G.A.; Zavaleta-Gatica, R.; Tiznado-Hernández, M.E. Improving postharvest quality of mango 'Haden' by UV-C treatment. Postharvest Biol. Technol. 2007, 45, 108-116. [CrossRef]

48. Rice-Evans, C.; Miller, N.; Paganga, G. Structure-antioxidant activity relationships between flavonoids and phenolic acids. Free Radic. Bio. Med. 1996, 20, 933-956. [CrossRef]

49. Xu, G.H.; Chen, J.C.; Zhang, Y.H.; Iang, P.J.; Ye, X.Q. Minerals, phenolic compounds, and antioxidant capacity of citrus peel extract by hot water. J. Food Sci. 2008, 73, 11-18. [CrossRef]

50. Ma, Y.Q.; Ye, X.Q.; Fang, Z.X.; Chen, J.C.; Xu, G.H.; Liu, D.H. Phenolic compounds and antioxidant activity of extracts from ultrasonic treatment of Satsuma Mandarin (Citrus unshiu Marc.) peels. J. Sci. Food Agric. 2008, 56, 5682-5690. [CrossRef] 
51. M'Hiri, N.; Veys-Renaux, D.; Rocca, E.; Ioannou, I.; Boudhrioua, N.M.; Ghoul, M. Corrosion inhibition of carbon steel in acidic medium by orange peel extract and its main antioxidant compounds. Corros. Sci. 2016, 102, 55-62. [CrossRef]

52. Van Acker, S.A.; Van Den Berg, D.J.; Tromp, M.N.J.L.; Griffioen, D.H.; Van Bennekom, W.P.; Van Der Vijgh, W.J.F.; Bast, A. Structural aspects of antioxidant activity of flavonoids. Free Radic. Biol. Med. 1996, 20, 331-342. [CrossRef]

53. Scattino, C.; Castagna, A.; Neugart, S.; Chan, H.M.; Schreiner, M.; Crisosto, C.H.; Tonutti, P.; Ranieri, A. Postharvest UV-B irradiation induces changes of phenol contents and corresponding biosynthetic gene expression in peaches and nectarines. Food Chem. 2014, 163, 51-60. [CrossRef] [PubMed]

54. Chaudhary, P.R.; Bang, H.; Patil, B.S. Variation in key flavonoid biosynthetic enzymes and phytochemicals in Rio Red grapefruit (Citrus paradisi Macf) during fruit development. J. Agr. Food Chem. 2016, 64, 9022-9032. [CrossRef]

55. Minas, I.S.; Tanou, G.; Belghazi, M.; Job, D.; Manganaris, G.A.; Molassiotis, A.; Vasilakakis, M. Physiological and proteomic approaches to address the active role of ozone in kiwifruit postharvest ripening. J. Exp. Bot. 2012, 63, 2449-2464. [CrossRef]

56. Minas, I.S.; Tanou, G.; Krokida, A.; Karagiannis, E.; Belghazi, M.; Vasilakakis, M.; Papadopoulou, K.K.; Molassiotis, A. Ozone-induced inhibition of kiwifruit ripening is amplified by 1-methylcyclopropene and reversed by exogenous ethylene. BMC Plant. Biol. 2018, 18, 358. [CrossRef]

57. Duarte-Sierra, A.; Aispuro-Hernández, E.; Vargas-Arispuro, I.; Islas-Osuna, M.A.; González-Aguilar, G.A.; Martínez-Téllez, M.Á. Quality and PR gene expression of table grapes treated with ozone and sulfur dioxide to control fungal decay. J. Sci. Food Agric. 2016, 96, 2018-2024. [CrossRef]

58. Lin, J.H.; Gong, D.Q.; Zhu, S.J.; Zhang, L.J.; Zhang, L.B. Expression of PPO and POD genes and content of polyphenolic compounds in harvested mango fruits in relation to Benzothiadiazole-induced defense against anthracnose. Sci. Hortic. 2011, 130, 85-89. [CrossRef]

59. Sachadyn-Król, M.; Materska, M.; Chilczuk, B.; Karaś, M.; Jakubczyk, A.; Perucka, I.; Jackowska, L. Ozone-induced changes in the content of bioactive compounds and enzyme activity during storage of pepper fruits. Food Chem. 2016, 211, 59-67. [CrossRef]

60. Ong, M.K.; Ali, A.; Alderson, P.G.; Forney, C.F. Effect of different concentrations of ozone on physiological changes associated to gas exchange, fruit ripening, fruit surface quality and defence-related enzymes levels in papaya fruit during ambient storage. Sci. Hortic. 2014, 179, 163-169. [CrossRef] 